\title{
Opinion, Idolatry, and Indigenous Consciousness: Bartolomé de las Casas' Approach to Human Sacrifice
}

\author{
José Cárdenas Bunsen
}

\begin{abstract}
This article addresses the criteria by which Las Casas conceptualized indigenous beliefs in his Apologética historia sumaria. It maintains that the theological and juridical notion of 'opinion' undergirds Las Casas' conceptualization of religious phenomena among native peoples. Las Casas argues that human sacrifice emanates from a search for the true god within the limits of human reason, is protected with all legal considerations granted to formal opinions held in good faith and does not provide grounds to justify colonial intervention.
\end{abstract}

\section{Keywords}

Human sacrifice - idolatry - colonialism - theology and law - opinion and belief

Framed within the imperial commitment to the conversion of the native peoples, early writings about the Americas charted indigenous customs and practices. Missionaries penned accounts of native religious beliefs throughout the continent; in so doing, they preserved a wealth of information related to the multifaceted forms of worship, sacrifices, and offerings. Bartolomé de Las Casas' Apologética Historia Sumaria (1527-156o) stands out among these writings for its far-reaching scope and, more importantly, for its careful conceptualization of religious phenomena. During the long years of its composition, Las Casas (1484-1566) incorporated information he collected during his travels to Hispaniola, Cuba and Mexico, and he also drew from the missionary works, among others, by Toribio de Benavente Motolinía $(\dagger 1568)$ on the complex religion of ancient Mexico, and his fellow Dominican Domingo de Santo Tomás (1499-1570) on the religious landscape of Peru (Silva 344-347). Las Casas did not limit his work to a comprehensive survey built on these sources; rather he created a framework, absent in his sources, to present his vast information as he laid the groundwork for a systematic interpretation of native beliefs. 
This study addresses the criteria by which Las Casas organized the religious information in his Apologética Historia Sumaria. It intends to complement recent scholarship that addresses the issue of human sacrifice in Las Casas' thought from a legal and anthropological point of view but without an identification of the criteria on which Las Casas supported his views on religion (Carman 285-291; Lantigua 2019: 285-309). This essay maintains that Las Casas articulated his views on native beliefs based on the notion of opinion, a theological and juridical category that refers to a state of knowledge superior to ignorance and doubt, but inferior to certainty. A key feature of this concept is its ability to be changed, for there is always the possibility to persuade someone of the value and weight of a different, even contrary, opinion from the one originally held. In the Aristotelian and scholastic tradition in which Las Casas operated, the formation of an opinion closely relates to the proper functioning of the human body, whose external and internal senses affect perception, the imagination, and the rise of ideas. From a theological point of view, opinions shape religious beliefs, for the act of believing presupposes a strong, already formed, opinion about the sacred. Thus, opinion is the elementary component of idolatry, which Las Casas considers to be a universal natural-law phenomenon that inclines individuals to embark on a quest for a maker of the universe within the limits of natural reason and independently from Christian revelation.

Opinion underlies Las Casas' presentation of native beliefs in his long narrative of the development of religious opinions region by region and case by case without disregarding their natural-law basis and the natural and supernatural forces that distort the quest of natural reason for the divine. Human sacrifice puts Las Casas' theoretical approach to the test. According to the Bishop of Chiapas, the practice appears as a development of the natural-law tendency of presenting offerings of the most esteemed gifts to either the false or the true God - that is, either to the deity conceived by natural reason alone or to the Christian God. Since true religion transcends the natural capabilities of reason, people committed to their opinion of the identity of their god act motivated by a conscience that is guided by natural law, even if it is erroneous from a Christian point of view. Such acts of the conscience would absolve them from punishment for violating natural law, which a canonist might argue was deserved. But human sacrifice also grew out of the opinions that the demons and their priestly caste spread, by which they convinced their followers that their gods demanded human life in exchange for their protection. Despite their compliance - Las Casas explains - people acceded to these demands with fear and sacrificed lives unwillingly: "los indios que hacían y hoy hacen sacrificios de hombres, no era ni es de voluntad, sino por el miedo grande que tienen al demonio" (Las Casas, Apologética Historia I: 424). 
This characterization of human sacrifice in the Americas contains Las Casas' contribution to the history of indigenous consciousness, for his theorization on opinion provided a coherent explanation of indigenous religions, created a framework to reflect the intellectual activity of native peoples in forming their beliefs, and furnished a legal argument to refute the charge that human sacrifice violated natural law and justified Spanish conquest.

I present my arguments in support of these hypotheses in two sections. The first section addresses the status of opinion in the scholastic tradition and explores ideas about the formation of opinions and its links to the functioning of the human body. The second part will focus on Las Casas' systematization of indigenous beliefs and the particular case of human sacrifice.

\section{Las Casas' Premises on Opinion, Idolatry and the Functioning of the Body}

At the center of Las Casas' reasoning on native religions lies the notion of opinion. At the time when Las Casas addressed Amerindian matters, opinion had been the subject of a long development in dialectical thinking in which it was established as a level of knowledge relevant to moral and theological reasoning.

In medieval epistemology, the attainment of a certain opinion was held to be the result of reflection. This conceptual result ended the mind's state of suspense as it rose above lower states of knowledge such as ignorance, doubt, and suspicion. Opinion, though, did not reach the highest level of certainty, given that it retained a degree of doubt (Albertus Magnus 2: 150-151). ${ }^{1}$ In the terms of Albert the Great (ca. 1206-1280), 'opinable' was a notion distinct from 'knowable.' The latter referred to universal conclusions to which the mind arrived based on universal premises through necessary, non-contingent reasoning; while the former relied, instead, on necessarily accepted premises that would operate as the basis to support the process leading to the formation of an opinion (Albertus Magnus 2: 149). Consequently, opinion results from an argumentative chain that proceeds not on necessary, but instead on contingent premises situated above mere conjectures and aspiring to a conclusion considered to be the likeliest in the mist of contingencies (Deman 26o, 265) ${ }^{2}$

1 For a thorough discussion about the category of opinion, see the study of Deman and the entry 'opinion' in Ferraris' compilation of canon law under "opinio."

2 The premises of this approach involve the assumption that both the functioning of nature and human actions are intrinsically contingent, they do not act always in the same predictable way (Aquinas, Summa Sacra 1.2.84.1). 
Thomas Aquinas (ca. 1225-1274) captured the nature of opinion in his definition: "Opinio significat actum intellectum nostri qui fertur in unam partem contradictionis cum formidine alterius" ("Opinion expresses an act of our intellect which makes an assertion on one part of a contradiction with fear of the other part," Aquinas, Summa Sacra I.79.9). In addition to the recognition of the intellectual activity required to arrive at an opinion, Aquinas also anticipates the necessity of a decision to assert one conclusion over another in the face of two seemingly valid, albeit contradictory, opinions. In fact, every opinion bears an inherent uncertainty that implies that the evidence on which it is based could have a different explanation; in other words, another opinion based on a firmer and likelier basis could replace a prior one. Therefore, opinion demands a certain acceptance, akin to faith, of certain propositions endowed with a degree of likelihood (Albertus Magnus 2: 150).

For these reasons, opinion was associated with the concept of the probable - "probabilis" in medieval terminology - identified with the judgement that all or the majority or the wise commended (Aristotle, Topica 10ob; Albertus Magnus 2: 267). The probable, also conceived as a quality that makes a particular opinion or judgment worthy of voluntary approval, was the matter out of which opinion was formed (Richard 94). Las Casas insistently referred to Amerindian beliefs as opinions. The Inca, for instance, greatly admired their wise rulers and thus "vinieron en opinión que aquellos eran más que hombres" (Las Casas, Apologética Historia I:434). The Totonaca people practiced a vocal confession that by itself demonstrated "la fe o opinión que tenían del Dios grande y de los otros dioses." Also, among the Aztecs, the high priest elevated the censer toward the sun "teniendo por opinión que del cielo y por mandado del sol habían descendido los otros dioses" (Las Casas, Apologética Historia II: 147; II: 190, respectively).

Las Casas' apparatus in his Apologética Historia points to the epistemology of opinion reconstructed above as its conceptual grounds (Las Casas, Apologética Historia I: 57, 79-86). For Las Casas, opinion is closely related to faith. Albert the Great explained their epistemological link in his classification of the different states of the mind in its confrontation with dialectical problems. He identified four different situations in which reason finds itself in its quest for knowledge:

dubitatio est indeterminatus motus rationis super partes contradictionis sine ratiocinatione consensum inclinante. Ambiguum autem est, quando ambit utramque partem per rationes aequipotentes. Opinio, autem, quando non confirmato quidem consensu complectitur alteram. Fides vero quando fortificatur in alteram sine fundatione in eadem scientia, aut quando fundatur per demonstrationem. 
doubt is an undetermined movement of reason over the parts of a contradiction without ratiocination inclining to a consensus. Ambiguity happens when [the mind] encircles both parts through equipotent reasons. Opinion, on the other hand, occurs when it embraces one part through an unconfirmed consensus, and faith when it is fortified in one part without foundation either in knowledge itself or through a demonstration.

ALBERTUS MAGNUS 6:134

It follows from this classification that opinion and faith represent similar states in which the movement of reason has already formed a certain judgment of a certain caliber, despite the fact that neither of the two represents an absolute certainty. However, faith reaches its conclusion with no demonstration, for it demands a leap of the will to attain the mind's assent. Because of its basis in likelihood, opinion is the type of intellectual judgment best suited to the making of moral decisions on what to avoid and what to choose rightfully.

Las Casas fully accepted this epistemological tradition and embraced it throughout his writings. His adoption of these premises is particularly clear when Las Casas dismantled the arguments of the defenders of Indian slavery. Las Casas fiercely opposed these enslavement procedures and undertook an intellectual rebuttal in which he laid out the legal principles that made Indian slavery illegitimate. Arguing that Spaniards in the colonies could not ignore the immorality of the practice, Las Casas quoted the well-known opinion of the mendicant orders who preached against this type of slavery and maintained that Spaniards had a moral obligation to follow the friars' opinion. In this context, he equated the opinion of the friars with the probable opinion of the learned wise men, as Aristotelian Topica conceptualized it:

ésta [la opinión de los religiosos sobre los indios esclavos] es la que se llama probable opinión, conviene a saber, cuando los más sabios y más experimentados, y más honestos y temerosos de Dios, y que menos interese pretenden, o la mayor parte dellos afirman y tienen o les parece una cosa ser verdad dañosa o peligrosa, como dice el Filósofo en el $1^{\circ}$ de los Tópicos; a los cuales son los hombres, al menos los que no tienen muchas letras, y comúnmente todos los seglares, obligados a creer y a seguir en las dubdas, señalada e infaliblemente si siguen y aconsejan aquello en lo cual no hay peligro alguno, o si lo hay es menor y de menos riesgo y daño que lo otro de que se duda; y si acaso yerran llámase probable error, y son los que los siguen escusados; y los que no los siguen, arrimándose antes a su parecer, yerran e ignoran improbablemente, y todo daño que de allí se sigue les es imputado. 
In addition, Las Casas inscribed the friars' opinion within the framework of the probable and further explained the associated concepts. In particular, he points to the notion of "probable error." This concept complements the opinio probabilis mentioned in the passage in the sense that opinions, as shown above, contain an intrinsic margin of error because of their reliance on likely propositions, which are contingent and able to be replaced with more solid ones. If an opinion induced someone to act in a certain way and it turned out to be an incorrect opinion, the individual who had followed it would be morally and even legally excused of any guilt, for he had committed an error based on an opinion he considered to be correct.

Beyond the legal domain, opinion also bears theological implications, which originate from the resemblance of opinion and faith as intellectual states to which the mind arrives through similar reflective activities. In exploring this connection, Las Casas relied on the theology of Guillaume d'Auvergne (ca. 1180-1249), specifically on his polemical treatise De fide et legibus devoted to discerning the nature of faith and the pillars of Christianity. The Bishop of Paris recognized faith to be the basis of religion, but he acknowledged that faith demands people to believe in many unlikely and non-evident principles; in this approach, belief presupposes a desire to choose it (Auvergne, Part 1, Chapter 1, section C). Because of this condition, belief is an intellectual operation able to be contested; it is also very different from knowledge, which is established on demonstrably necessary premises. In Auvergne's views, belief is akin to a strong opinion, "Comprehendimus autem opinari in eo quod est credere quoniam credere quoddam opinari est. Credere enim est vehementer opinari" (Thus, we comprehend to opine in that which pertains to belief, because to believe is a certain kind of opining; for to believe is to opine vehemently, Auvergne, Part 1, Chapter 1, Section D). ${ }^{3}$ Auvergne's conceptualization of opinion undergirds his reflection on natural theology; he finds the root of idolatry in humanity's original sin which corrupted the human desire for and tendency to believe the supreme truth - and he identifies the supreme truth with God. Idolatry also directed that natural desire towards "other truths," which are weak and vile in nature; but human desire misidentified them with divine truth. On the grounds of this natural appetite for the supreme truth, Auvergne declared the universality of idolatry:

Servitus divina sive cultus divinus sive verus sive erroneous universalis est: hoc est apud omnes nationes a perpetuus pene enim nullo tempore

3 It is relevant to note that opinions could have different calibers and degrees of acceptance. It could be an individual opinion or an opinion commonly shared by many; it also could be felt reflexively or vehemently (Gardeil 474-482). 
defuit ydolatria vel verus dei cultus ex quo homines multiplicari ceperunt et adhuc ydolatria apud omnes gentes est vel in capitalibus suis vel in ramis vel in reliquis adeo autem adherens: ut nec igne nec gladio vel alia via adhuc exterminari possit.

Divine service or divine worship, either true or erroneous, is universal: it exists among all nations perpetually, for idolatry or true divine worship was almost never absent since men began to multiply. And hitherto idolatry exists among all nations, and it is so firmly fixed to their headbands or branches or relics that it could not be exterminated either by fire or the sword or in any other way.

AUVergne, Part 8, chap 2, Sections C

Las Casas construed his notion of idolatry based on this definition by Guillaume d'Auvergne, and from it he derived two important implications: the natural universality of idolatry and its status of being an opinion. This combination emerged in his paraphrase of Auvergne's ideas in which Las Casas described the intellectual operations that follow the natural desire to know the divine:

Deste continuo apetito, deseo, inclinación y hambre natural de nuestra potencia racional por saber verdades, y de nuestra potencia concupiscible buscar bienes en que deleitarse, y de la irascible pugnar y no dar lugar a lo contrario que lo impide, venerando el objeto de la concupiscible, necesariamente se sigue no poder ser nuestra racional potencia sin alguna opinión y creencia falsa o verdadera.

LAS CASAS, Apologética Historia I: 242 (Italics added)

The whole dialectical framework and writings of Auvergne underlie this conceptualization. Moreover, idolatry is the result of a complex intellectual process that naturally suggests concrete religious ideas, and people put them into practice in the form of worship and honors rendered to what is considered a divine being. By virtue of this quest for the divine which is ingrained in the human mind, idolatry becomes a natural, universal phenomenon:

Cuando quiera que faltó gracia y doctrina y no hobo quien guiase y enderezase los ánimos de los hombres [...] la [potencia] racional fue a parar en creencias y opiniones de diversos errores y la concupiscible en desear y deleitarse en impuras y no verdaderas bondades, y la irascible a dar la honra, obediencia y servidumbre de las criaturas que a solo Dios se debía, conviene a saber, a aquellas cosas en las cuales alguna señal o apariencia de bondad o excelencia se cognoscía, que llamamos ídolos, o a las 
cosas que representaban los ídolos, porque cualquiera bondad y alteza y nobleza que las criaturas tienen o muestran, no son sino vestigios y semejanzas del altura, excelencia, y majestad divina, y veis aquí la idolatría contraria de la latría y reverencia y culto divino que a solo Dios se debe, por el mundo introducida, porque natural cosa es a nuestra humana naturaleza humillarnos y ofrecer nuestra subjeción y hacer reverencia y dar honor a aquello que es superior a nos según nuestra estima.

LAS CASAS, Apologética Historia I: 242-243 [Cap.73]

Beyond the theological background outlined above, Las Casas was a realist: these principles must be anchored in the intellectual capacities of Amerindian peoples. In the Apologética Historia, he discussed at length the conditions for the birth and growth of people in the Indies as part of the proto-anthropological framework that Las Casas created to historicize the emergence of political prudence in the continent (Cárdenas Bunsen 247-249). The framework presents the geographical and climatic conditions for natural human generation, and Las Casas later proves that the bodies and souls of the peoples born under these conditions work properly (arguing against the ancient idea of the uninhabitable Torrid Zone). For this section of his investigation, Las Casas continues to rely on the Aristotelian legacy regarding the soul that Albert the Great and Thomas Aquinas further developed (MacCormack 225). ${ }^{4}$ In this tradition, the relation between the soul and the body, and the configuration of each, play a central role in the formation of opinions and in the mechanics of intellectual operations. Las Casas remarks on the connection between body and soul, arguing that a well-developed soul requires a well-formed body (Las Casas, Apologética Historia I: 73-80).

Las Casas embraces the premises of the Aristotelian legacy on the body according to which it works in tandem with the soul to make possible the faculties of nutrition, sensation, thought and movement. The body feels through the senses and mediates the perceptions of the soul, for knowledge and thought arise from sensible things (Aristotle, On the Soul 413b; Albertus Magnus 5: 118). The external senses' provision of sensorial information to the internal senses sets in motion complex intellectual operations (Aristotle, On the Soul 413b, 426b; Albertus Magnus 5: 303, 316-318, 328; Michaud-Quantin 69). Writing in

4 Wey Gómez (99-100) points out that Albert the Great's geographical views shaped Las Casas anticolonial considerations on the location of the Indies and their heavens and grounds. This scholar keenly contends that Las Casas's choice is a form of discussion with Pierre d'Ailly's thesis on the same matters that reinforced the colonial enterprise. In a similar manner, it is fair to add that Albert's studies on the soul and his investigation on Aristotle's Topica informed Las Casas's conclusions on these particular matters. 
his eyewitness capacity, Las Casas offers proof of the optimal functioning of the external and internal senses in the peoples of the Indies by referring to the natives' ability to stage sacred plays, their talent to paint, their intelligent learning of the liberal arts and their remarkable execution of the crafts that they have acquired, which attest to their common sense, memory, judgement, imagination and fantasy, that is, to the potency of their internal senses (Las Casas, Apologética Historia I: 213-219).

Beyond the verification of the optimal activity of body and soul, there is further connection between their functions and the generation of opinions. For Aristotle asserted that knowing, perception, and the formation of opinions are operations of the soul (Aristotle, On the Soul 411a). Specifically, two internal senses, imagination and phantasy, are necessary in order to form judgment and opinions, but these two are not the same. Opinion and judgment both imply understanding, but the first is further differentiated from the second based upon the fact that opinion demands acceptance, which requires a dose of faith to assent to a particular opinion, even when one fears that it could be false, as noted above (Albertus Magnus 5: 323-325).

There is an additional relation between phantasy and opinion, which is important in explaining why Las Casas chose the second to be the theological and legal category that sustains his account of Amerindian religious beliefs. Deliberating reason could influence phantasy, direct it, and incline its appetite according to its meditations. Thus, from the mental images already elaborated by the internal sense of phantasy, reason selects those images considered best on the basis of its opinions, and in this manner, opinion can influence phantasy and shape the appetite and desires (Albertus Magnus 5: 407-408). Therefore, opinion is deeply interconnected with the body, soul and their intellectual capacities and activities.

As an epistemological category, opinion represents the attainment of a level of knowledge that stems from probabilistic reasoning. In anchoring its generative mechanism in human abilities, opinion results from the good functioning of the external senses of the human body and their joint action with the internal senses. In this reciprocal relation, opinion influences and even shapes the mental images elicited by phantasy, which synthesizes the information that the other internal senses transmit. Therefore, opinion molds the apex of the mind's activity, and thus it becomes a potential element to be imitated at the moment when phantasy shapes the appetite and desires. Its centrality in the workings of human consciousness explains why Las Casas positioned opinion at the center of his presentation of Amerindian religion. For his protoanthropological project, the final step consisted in his effort to historicize the formation of those religious opinions throughout the Indies. 


\section{Opinion, Indigenous Consciousness and the Legal Case of Human Sacrifice}

The implications of the functioning of opinion, its kinship with the notion of belief, and its influence on human intellectual activity likely convinced Las Casas to focus on opinion as the main element in his detailed account of native customs and beliefs. The quasi-equivalence established between belief and opinion paved the way to introduce indigenous religious concepts as opinions in several instances, thus explaining key tenets of indigenous faith as concepts that reflect the rationality and interior consciousness of the people who professed them. In documenting Mexican beliefs, for instance, Las Casas explicitly refers to the high esteem in which the natives hold their gods in terms of opinions:

Cuanto a la sanctidad que por la devoción y opinión del pueblo se le recrecía, nunca jamás en ninguna gente de las erradas por la idolatría, en el mundo se vido, que más devoción, ni mayor, ni tanta opinión tuviese de sus dioses o ídolos, así creyese su santidad y por consiguiente fuese más solícita en la observancia de su religión que aquestos indios. Esto asaz puede haber sido manifiesto si se ha querido mirar en ello, por lo mucho que de los dioses y de los templos queda dicho y mucho más claro parecerá de que tratemos de los sacrificios.

LAS CASAS, Apologética Historia I: 456 (Italics added)

Las Casas gives a similar account of the pagans of the ancient world, speaking of their "uso y opinión" in religious matters in order to compare them to those of the Indies (Las Casas, Apologética Historia II: 37).

The underlying categorization of Amerindian beliefs as opinions informs his entire discussion of Amerindian religion which, in turn, composes the fifth part of the Aristotelian polity. The whole Apologética Historia intends to show that the different parts of Amerindian societies conform to the cities and polities that Aristotle's Politics describes, which demonstrates the political prudence of Amerindians (Las Casas, Apologética Historia I: 198). Despite the wide territorial extension of the Indies and the heterogeneity of native beliefs, in this section of his book Las Casas aims at organizing, explaining, and presenting the historical formation of the opinions that configured the religious landscape under consideration.

Arising from the interaction between opinion and phantasy, Amerindian religious beliefs connect with a chain of premises that Las Casas considers to be natural in human beings thanks to the action of synderesis, a natural habit 
that exists, according to Thomas Aquinas, in human reason. Synderesis permits men to access principles such as the tenets of natural law, the preservation of the self, the inclination to follow the good and avert evil (Aquinas, Summa de veritate, Materia 16, quaestio 1; Las Casas, Apologética Historia I:134-135). From synderesis also springs a universal desire to initiate a quest to know the divine. Las Casas acknowledges this tendency in his collection of religious customs from around the world:

El hombre naturalmente es inclinado y desea saber las verdades, mayormente cognoscer a Dios, por lo cual dijo Aristóteles en el principio de su Metaphísica: Omnes homines natura scire desiderant.

LAS CASAS, Apologética Historia I: 135

From this anthropological premise, the universal reach of religion ensues; idolatry gains the status of being a universal phenomenon integral to human nature for those peoples previous to - or coeval with, but outside of - Christianity, given that idolatry includes a natural-law conclusion according to which the world has a maker (Las Casas, Apologética Historia I: 240). This complex argument explains the widespread belief in the existence of a supreme being that Las Casas charts across the Indies. From the Caribbean to Guatemala, Mexico and Peru, Las Casas documents some faint knowledge of the true God naturally instilled in people which takes the appearance of a belief in a creator and lord of the world thought to be invisible in some places, despite the fact that many peoples identified him with the sun (Las Casas, Apologética Historia I: 416, 420, 428). However, the idea of God appears mixed with spurious beliefs which Las Casas attributes to various causes (Las Casas, Apologética Historia I: 428, 432). The active work of the demons spreading falsehoods to occupy the place reserved for God is to blame in the majority of cases (Las Casas, Apologética Historia I: 246). The devil counted on the assistance of his ministers whom he appoints and favors in order that they will help him spread his lies. In most places, these ministers tend to institute a priestly caste and to become a source of false opinions that target the imagination and phantasy of the natives and make them believe that good comes from the idols and false deities they promote (Las Casas, Apologética Historia I: 416-418). Las Casas repeatedly describes this pattern:

El demonio, lo primero que acostumbró al principio que quiso introducir en el mundo la idolatría, fue constituir ministros y sacerdotes della, por engaño que hacía a los más dispuestos que para ello en malicia y astucia hallaba, para que por medio de aquellos su poco a poco a todos los demás 
engañase, y cómo estos sean, por sus ficciones y prestigios que hacen, de los pueblos y gente simple venerados y acatados, y así alcanzan honra y estima y dádivas y lo que más la soberbia y cudicia les demanda, y por la predicación de la fe y doctrina cristiana todo aquello se les desbarata.

LAS CASAS, Apologética Historia I: 430

What follows from this account in the larger argument of the Apologética Historia is that these lies and deceptions through the words and deeds of these ministers persuade the native minds, and thus false opinions arise from false premises.

Writing from the position of an early modern bishop and taking Catholic tenets as the only true standard, Las Casas maintains that the basic intuition of monotheism, attainable through natural reason, blends with a wide variety of ancillary beliefs, such as the attribution of a mother and a brother to God among the natives of Hispaniola (Las Casas, Apologética Historia I: 416). Despite these errors, Las Casas insists on presenting the rationale behind those opinions that explain why and how the natives chose their gods. Some of them adopted as their deities those entities considered to be their providers of water, wind, and sun; others selected the protectors of the earth, skies, and everything else (Las Casas, Apologética Historia I: 417, 421). Some people deified their wise rulers, as occurred in some places in the Andes, where the natives reported that "veneraban a señores que habían tenido, porque los habían blanda y suavemente gobernado, y así poco a poco vinieron en opinión que aquellos eran más que hombres" (Las Casas, Apologética Historia I: 434). In discussing the case of Hispaniola, Las Casas recalls his interest in the indigenous observance of offering first fruits to their gods and his care in asking the natives who their Cemí, the local ancestral deity, was. To which they answered, "el que hace llover y hace que haya sol, y nos da los hijos y los otros bienes que deseamos" (Las Casas, Apologética Historia II: 121). Their response carried the implication that they held the rational opinion that their god was a provider. This realization led Las Casas to preach Christianity and to consider that making offerings was a universal religious behavior (Las Casas, Apologética Historia II: 121). In a similar manner, Las Casas reports that the Spaniards newly arrived to the Floridian province of Quivira conferred with King Tartaraz who, when asked whether he revered wooden idols, responded that he only worshiped the sun and the moon because his people receive food and sustenance from the sun and health from the moon. Las Casas again includes the reasons for the king's belief (Las Casas, Apologética Historia II: 126). In sum, Las Casas' account of Amerindian beliefs displays the reasons that give strength to the opinions on which each particular faith rests. In so doing, Las Casas created an analytical 
apparatus that cohered with the indigenous consciousness and that mirrored the intellectual activity of the believers with its natural-law components and the external elements that reflected their actual belief. From this perspective, his Apologética Historia is not just a collection of detailed ethnographic information, but also an effort to portray the conscious and intellectual underpinnings of natural religion as attested in the Indies.

Adhering to Aristotle's account of the role of religion in the constitution of a well-established polity, Las Casas focused first on deities, for they compose the primordial part of religious beliefs. The second part of his account addresses temples, which Las Casas remarked were consistently centrally located, generously endowed by the rulers, and industriously sustained. The third part discusses the priestly caste, about which Las Casas regretted his lack of sufficient details. Sacrifice and offerings ensued, to which he devotes considerable attention. His approach to sacrifice is not an exception to the scheme of his Apologética Historia, for the notion of opinion informs his account of sacrifice.

Las Casas realized in Hispaniola that sacrifice was a universal natural behavior. He confirmed as an eyewitness a well-established tenet of natural theology about which he had only read before (Las Casas, Apologética Historia II: 121). He defined sacrifice as an exterior recognition of what was considered the most excellent being, that is, God (Las Casas, Apologética Historia II: 33-34). The variety of sacrificial practices, the different nature of the sacrificial gifts ranging from artifacts, plants and animals to human victims, and the careful observance of the rituals prompted Las Casas to conclude that the preciousness and excellence of the gifts offered in sacrifice reflect the high esteem in which a certain people held their gods, which, in turn, attests to the complex rational steps that sustain those beliefs (Las Casas, Apologética Historia II: 167). In fact, Las Casas outlines the sequence whereby the rituals and protocols of offerings and sacrifices were established:

Por manera que sacrificios no tenían ningunos, porque como de todo el discurso que habemos traído, refiriendo los dioses, y templos y sacerdotes, y sacrificios de las gentes antiguas y destas indianas, puede colegirse, según el concepto y estimación que los hombres de Dios alcanzaron, así le tuvieron la devoción y le constituyeron los templos, y hobo el sacerdocio e inventaron y ordenaron los sacrificios, y, por consiguiente, fueron en ceremonias más o menos religiosas; de manera que, de lo primero necesariamente se siguió lo segundo y de lo segundo lo tercero y de lo tercero los sacrificios, que es lo último. 
Since they are a consequence of this rational sequence, sacrifices not only reflect the level of civilization of a certain group, but also reveal both its crystallization of natural law that demands the making of sacrifices and its freedom to determine the specific offering. This explains the wide variety and forms of sacrifices, for every polity would regulate its calendar, its rituals and the kind of sacrifices and victims (Las Casas, Apologética Historia II: 34). There is, though, a particular kind of oblation which renders human victims and from which almost no nation - including Spain - was an exception (Las Casas, Apologética Historia II: 98). ${ }^{5}$ In the Indies, the Inca and the Mexica practiced human sacrifice, but the latter stood out for being the one nation that exceeded all the rest in the scope, amount and complexity of their sacrificial rituals. With the framework that Las Casas created to approach religion, the exacting demand of human sacrifice is commensurate with the attributes that Mexicas ascribed to god through the sole guidance of reason, though he also noted some demonic menaces in the realization of this practice that made it not entirely a voluntary offering (Las Casas, Apologética Historia II: 121, 128). The Mexicas sacrificed prisoners of war in the ceremony of the new fire at the end of the calendar cycle of $5^{2}$ years; they also observed a Lenten period in which they again offered prisoners of war as victims for the common good. Prior to their sacrifice, these prisoners underwent a ritual sacralization consisting of freeing them and granting them exceptional treatment in preparation for becoming victims in honor of their idols, through which their prayers for health, prosperity and protection would be heard. Later they would cook and eat the sacralized flesh of these victims (Las Casas, Apologética Historia II: 129, 150-152). The sacrifices to Tlaloc, god of water, originated from the periodic occurrence of draughts, and - upon consultation of an oracle and the instructions of the priests - from the attempt to please the god and implore him to bring rain by offering him the precious gift of children's lives (Las Casas, Apologética Historia II: 132). Among the Totonacas, human sacrifice involved a communal dimension. Influenced by the Mexicas, Totonaca priests preached that the sun was the maker of the universe and that he would send his son to earth to renew it and to lengthen human lives. To implore the sun to make good on these promises, the community selected messengers to deliver the collective plea to free them from the burden of human sacrifice which they

5 In his vast compilation of rites and customs, Las Casas draws the reader's attention to those practices held in Spain in Pre-Christian times such as the human sacrifices offered to Mars (Las Casas, Apologética Historia II:53). It is a repeated intent, throughout his works, to establish comparisons between the Indies and Spain in several aspects of their customs and, particularly, in their similar religious history that began in infidelity and culminated in the conversion to Christianity (cf. Historia de las Indias I:16-17). 
offered as penance for their sins (Las Casas, Apologética Historia II:145-146). In the last two cases, Las Casas observes that the people did not make these sacrifices willingly but rather out of the fear mostly instilled by demons' menaces of future disasters and misfortunes, unless sacrifices be performed. This sentiment contrasts with the worship of Quetzalcoatl, for this deity rejected human sacrifice and generated an admiration and love above the other gods from the people (Las Casas, Apologética Historia I: 424-425).

Las Casas concludes his discussion of the mental activity that undergirds sacrificial belief by stating that the natives' intention in performing human sacrifices was to honor the god that they considered to be the true god (Las Casas, Apologética Historia II: 167). Natural law sanctioned the offerings and sacrifices, though there was no positive law about what the offerings should be.

The Apologética Historia's meditation on human sacrifice is the textual locus where Las Casas solidified the grounds to settle the debate in which he engaged with Juan Ginés de Sepúlveda (1494-1573) at Valladolid in $155^{\circ}$ and $1551 .^{6}$ Las Casas was aware that he had crafted a unique account of human sacrifice. In 1564, Las Casas wrote a letter to the Dominican chapter of Chiapas and Guatemala in which he acknowledged the coincidence of his opinions and those of prominent theologians of the School of Salamanca. With regards to human sacrifice, Las Casas proudly stressed his pioneering treatment of the subject: "probé muchas conclusiones que antes de mí nunca hombre las osó tocar ni escribir, e una dellas fue no ser contra ley natural seclusa omni lege positiva humana vel divina, ofrecer hombres a Dios, falso o verdadero (teniendo el falso por verdadero) en sacrificio" (Las Casas, Obras 13, 355; see Carman 278-280). In particular, his reflection on human sacrifice confirmed his profile of the fourth type of barbarians to complement the arguments he advanced in Valladolid and mustered the factual ammunition to demolish the legal and theological case for human sacrifice as justification for the Spanish war of conquest.

During the Valladolid dispute, Las Casas argued against Sepúlveda's characterization of Amerindians as outright barbarians and even natural slaves by appropriating Aquinas' analysis of the three different meanings of the word 'barbarian' according to its usage in Saint Paul's epistles and Aristotle's philosophy. Aquinas maintained that 'barbarian' refers to foreigners, to those that speak a language different from one's own, and to those with a strong corporeal makeup and lack of reason, deprived of laws and community (Aquinas, Commentaria, Ad Corinthios, lectio 2, sub si ergo nesciero). Also, Aquinas distinguished between barbarians 'simpliciter', that is, barbarians absolutely

6 The Valladolid debate was a watershed moment in the early intellectual history of the Indies. For thorough details, see Wagner and Parish 170-182 and Losada 279-306. 
and without reserve, and barbarians 'secundum quid,' that is, barbarians in a certain respect, be it nation, language, or gender (Aquinas, Commentaria, Ad Corinthios, lectio 5, sub Graecis ac barbaris). Las Casas borrowed this tripartite distinction for his intervention at Valladolid. Nonetheless, the passage of time between this debate and the conclusion of his Apologética Historia sufficed for Las Casas to add a fourth category of barbarian which he identified with infidels. This addition constitutes Las Casas' contribution to the discussion; he borrowed the old legal and theological notion of infidelity, which Aquinas had anticipated but not thoroughly developed in his commentary on the Pauline epistles. ${ }^{7}$ Las Casas then addressed the ambiguity of maintaining that human sacrifice conforms to a highly sophisticated form of natural law, while he attempted to avoid the risk of seeming to support a practice at odds with the consensus of his missionary peers. His solution took the form of a series of observations on the limits of natural reason and the necessity of Christian doctrine, noting that natural reason is able to rise to the idea of monotheism but not to that of the Trinity; and that moral, rational virtues are exceeded by the supernatural, theological virtues granted only through baptism (Las Casas, Apologética Historia II: 179-180). Biblical loci and authoritative passages of Church fathers buttressed these arguments: in particular, the Book of Wisdom's declaration that only the Holy Ghost properly orders human acts, along with Lactantius' claims that the discordance between faith and the customs of infidels reveals that they remain rude and unwise despite any knowledge of liberal disciplines. Lactantius brings up the practice of human sacrifice as proof (Las Casas, Apologética Historia II: 439). In the context of arguments developed in the Apologética Historia, the opinions that infidels reached through natural reason and crystallized through natural law lay at the core of his characterization of this type of barbarians. In Las Casas' view, Amerindian idolatry, aside from being a barbarity secundum quid, does not fall outside of natural law. Thus, he does not differentiate these infidels from other people except for their lack of Christian doctrine and their pre-baptismal status that would be remedied through conversion.

In 1527 Las Casas had planned that his Apologética Historia would be part of his Historia de las Indias. In the aftermath of the Valladolid debate, and in order to cement his defense of American Indians, he recast it in a polemical fashion and completed it between 156o and 1561 (Wagner and Parish 195-204, 287-289; Adorno 2008: 93-95). At Valladolid, Sepúlveda put forward four arguments to make the case for waging war against Amerindians: their idolatry and sins against nature, their natural barbaric condition, their cannibalism and

7 For a discussion on the status of infidels and the legal and theological implications of the concept, see Muldoon 19, 141; Lantigua 2020: 74-140; and Capéran I: 4-7, 29. 
human sacrifice, and the European goal of preaching the Christian faith (Las Casas, "Aquí se contiene" 229-231). In his own Apología, Sepúlveda further justified this war by invoking the papal power to force peoples to obey natural law to which all men are subject. He quoted many legal authorities in support of this point, among which Innocent IV's gloss on the canon Quod super his, de voto stands out (Sepúlveda 20o). Innocent IV (†1254) provided Las Casas with legal arguments to demonstrate the rightful dominion of infidels over their property and lordships; but Innocent also affirmed that the pope could exercise his temporal power to punish infidels who acted against natural law and worshiped idols (Innocent, ad c.8.X.III.34). Las Casas deemed this portion of Innocent's opinion to be a blatant error (Las Casas, Apología 124-134). In his rebuttal, which appears throughout his Latin Apologia, his controversy against Sepúlveda and his Apologética Historia, Las Casas outlined a legal argument that would prove that ignorance and probable error shielded the natives from believing that human sacrifices were against natural law. First, idolatry emanates from the natural-law search for the maker of the universe; this quest engendered particular beliefs which were juridically equivalent to a vehement opinion (Auvergne Pars 1, cap.1, D). Second, Las Casas' arguments make clear the difficulty of demonstrating to the natives that human sacrifices contradicted natural law, since reason leads to the opposite conviction according to the premises laid out in his Apología. Natural law teaches that men owe human sacrifices to the true god or even to a false deity if it is thought to be true (Las Casas, "Aquí se contiene" 399-401). In his Apologética Historia he would later contend that human sacrifice mirrored the elevated opinion that natives hold of their gods (Las Casas, Apologética Historia I: 456). Natives do not ignore the mandate to present offerings, including human victims, to god; they ignore, though, the identity of the Christian God. They followed the probable and common opinion of their rulers and wise men in religious matters. In raising this argument, Las Casas rejected Sepúlveda's narrow definition of probable opinion, which restricted the ability to hold probable opinions only to non-barbarian, political and human peoples (Las Casas, "Aquí se contiene" 321). ${ }^{8}$ Las Casas rather expanded the notion of probable opinion in order to include the religious opinions held by the wise and prudent of any nation, even if they were erroneous from a Christian perspective. His intention was to attribute to the native common opinion the same status that the communis opinio received in legal doctrine. Las Casas reiterated that the communis opinio is

8 The meaning of 'human' in this context does not convey the fixed sense of 'human race, humanity'; rather it refers to the customs and civic virtues that make a people able to selfgovernance. For a thorough discussion see Adorno 2008: 106, 115-117. 
a kind of probable opinion defined by the support of the wise who might err only from the perspective of divine law but not from the perspective of natural law. He added that "por esta manera dicen los juristas que communis opinio inducit errorem probabilem, ut in cap. único iuncta glosa de postulatione prelatorum, libro 6, ff. de iure et facti ignoratia" (Las Casas, Tratados 411). The relevant loci of civil and canon law clarified the implications of the argument. Roman civil law established that "ignorantia facti excusat sed not ignorantia iuris" (Ignorance of facts excuses, but ignorance of the law does not, Corpus iuris civilis D.22.6.1-2). In glossing the canon that Las Casas referred to, canon law makes a similar conclusion, "iuris ignorantia nec est probabilis nec excusat" (Ignorance of the law is not probable ignorance and it does not excuse, Catholic Church, c.1.1.5.in vi sub probabiliter).

It follows from these legal principles that idolaters and practitioners of human sacrifice did not ignore the natural-law mandate in presenting offerings, including human victims, to god; in fact, their synderesis searched for the true divinity, and the defense of their creed and rituals was lawful under natural law. They ignored, though, the Christian God, whose identity could not be discovered by reason alone, but only through revelation. Their rational religious conviction engendered an erroneous conscience that induced them to act in accordance with it. Their actions do not constitute sins because they proceeded erroneously only accidentally (per accidens); their intention was to honor the true God (Aquinas, Summa Sacra 1.2.19.6). From the perspective of both canon and civil law, human sacrifice and idolatry were not just cause for military interventions.

Las Casas furnished his anthropological perspectives on native beliefs on the epistemological, legal and theological basis of the notion of opinion, which lent him the mold to cast Amerindian religion as the expression of a complex activity of indigenous reasoning that fit neatly into the patterns of natural law and that had reached the summit of what it could attain without the assistance of Christian faith. Las Casas' intellectual achievement is an expression of a distinctive attribute of colonial letters identified by Adorno, that of simultaneously occupying positions in multiple disciplines when laying out an argument (Adorno 1988: 14). In the context of his Apologética Historia, the bishop's reliance on the manifold implications and sources of 'opinion' and its power to engage the main disciplines of his time - theology and the law - allowed him to make a compelling argument, one that found within the extraordinary circumstances of the indigenous cultures' abilities and beliefs that simultaneously responded to universal principles and were incarnated in specific, particular forms, none of which constituted grounds for just war and colonial domination. 


\section{Works Cited}

Adorno, Rolena. "Nuevas perspectivas en los estudios literarios coloniales hispanoamericanos." Revista de Crítica Literaria Latinoamericana 28 (1988):11-28.

Adorno, Rolena. The Polemics of Possession in Spanish American Narrative. New Haven: Yale University Press, 2008.

Albertus Magnus, Saint. Opera Omnia. Ed. Augusti Borgnet. Paris: Ludovicus Vives, 189 o.

Aquinas, Thomas. Commentaria in Omnes Epistolas Beati Pauli Apostoli. Basel: Michael Furter, 1495.

Aquinas, Thomas. Summa de Veritate. Colonia, 1497.

Aquinas, Thomas. Summa Sacra Theologia S. Thomae Aquinatis, doctoris angelici cum comentariis R.D.D. Thomae de Vio Caietani. Hildesheim: Georg Olms Verlag, 2000.

Aristotle. On the Soul. Transl. W.S. Hett. Boston: Harvard University Press, 2000.

Aristotle. Topica. Transl. Hugh Tredennick and E.S. Forster. Boston: Harvard University Press, 2004.

Albernus, Guglielmus. De fide et legibus [1249]. Habsburg: Günther Zainer, 1476.

Capéran, Louis. Le Problème du Salut des Infidèles. Essai historique. Toulouse: Grand Séminaire, 1934 .

Cárdenas Bunsen, José. Escritura y derecho canónico en la obra de fray Bartolomé de las Casas. Madrid: Iberoamericana Vervuert, 2011.

Carman, Glenn. "Human Sacrifice and Natural Law in Las Casas' Apologia." Colonial Latin American Review 25.3 (2016): 278-299.

Casas, Bartolomé de las. Apologética Historia Sumaria. Ed. Juan Pérez de Tudela Bueso. Biblioteca de Autores Españoles 105-106. Madrid: Atlas, 1958.

Casas, Bartolomé de las. Historia de las Indias. Edited by Agustín Millares Carlo with an introductory study by Lewis Hanke. México, Fondo de Cultura Económica, 1995.

Casas, Bartolomé de las. Apología o declaración y defensa universal de los derechos del hombre y de los pueblos. Ed. Vidal Abril Castelló. Salamanca: Junta de Castilla y León, 2000.

Casas, Bartolomé de las. “Aquí se contiene una disputa o controversia entre el obispo don fray Bartolomé de las Casas ... y el doctor Ginés de Sepúlveda, coronista del emperador." Tratados: 216-459.

Casas, Bartolomé de las. "Este es un tratado que el obispo de la Ciudad Real de Chiapas, don fray Bartolomé de las Casas o Casaus, compuso, por comisión del Consejo real de las Indias, sobre la materia de los indios que se han hecho en ellas esclavos." Tratados: 500-641.

Casas, Bartolomé de las. Obras completas. Madrid: Alianza Editorial, 1995.

Casas, Bartolomé de las. Tratados. Mexico: Fondo de Cultura Económica, 1997. 
Catholic Church. Liber Sextus Decretalium cum apparatu Johannis Andreae. Roma: Ulric Han et Simon Chardella, 1472.

Corpus Iuris Civilis. Eds. Theodor Mommsen and Paulo Krueger. Berlin: Weidmann, 1928.

Deman, Th. "Probabilis." Revue des Sciences Philosophiques et Théologiques 20 (1933): 26o-29o.

Ferraris, Lucio. Bibliotheca canonica, juridica, moralis, theologica. Venice: Vincent Radici, 1770.

Gardeil, A. "La Certitude Probable." Revue des Sciences Philosophiques et Théologiques 5 (1911): 237-266, 441-485.

Innocent IV. Apparatus super Libros Decretalium. Venice: Joannes Herbort, 1481.

Lantigua, David. "Religion within the Limits of Natural Reason: The Case of Human Sacrifice." Bartolomé de las Casas, O.P. History, Philosophy and Theology in the Age of European Expansion. Eds. David Thomas Orique, O.P. and Rady Roldán-Figueroa. Leiden: Brill, 2019: 280-309.

Lantigua, David. Infidels and Empires in a New World Order. Early Modern Spanish Contributions to International Legal Thought. Cambridge: Cambridge University Press, 2020.

Losada, Angel. "The Controversy between Sepúlveda and Las Casas in the Junta of Valladolid." In Bartolomé de las Casas in History. Toward an understanding of the Man and his Work. Eds. Juan Friede and Benjamin Keen. Dekalb, IL: Northern Illinois University Press, 1971: 279-308.

MacCormack, Sabine. Religion in the Andes: Vision and Imagination in Early Colonial Peru. Princeton, NJ: Princeton University Press, 1991.

Michaud-Quantin, P. “Albert le Grand et les Puissances de l'Ame." Revue du Moyen Age Latin 11 (1955): 59-86.

Muldoon, James. Popes, Lawyers and Infidels. The Church and the Non-Christian World 1250-1550. Philadelphia: University of Pennsylvania Press, 1979.

Richard, R.P. Le Probabilisme Morale et la Philosophie. Paris: Nouvelle Librairie Nationale, 1922.

Sepúlveda, Juan Ginés de. "Apología en favor del libro sobre las justas causas de la guerra." Obras Completas III. Ed. A. Moreno Hernández and transl. Ángel Losada. Pozoblanco: Ayuntamiento de Pozoblanco, 1997.

Silva Tena, Teresa. "El sacrificio humano en la Apologética histórica." Historia Mexicana $16.3(1967): 341-357$.

Wagner, Henry Raup/Helen Rand Parish. The Life and Writings of Bartolomé de las Casas. Albuquerque: The University of New Mexico Press, 1967.

Wey Gómez, Nicolás. The Tropics of Empire. Why Columbus Sailed South to the Indies. Cambridge, MA: The мiт Press, 2008. 